\title{
FINANCIAL FOCUSING ON ECONOMIC DEVELOPMENT SUSTAINABILITY
}

\section{Kristijan Ristic}

Faculty of Business and Law of the "Union - Nikola Tesla" University, Belgrade, Serbia

\section{Stanislav Pantovic}

University of bussines studies, Banja Luka, Bosnia and Herzegovina

\section{Zeljka Gagovic}

University of bussines studies, Banja Luka, Bosnia and Herzegovina

\section{Marko Brckalo}

University of business studies, Banja Luka, Bosnia and Herzegovina

OMESTE

JEL Category: F63, F65, 011, Q01

\begin{abstract}
The contemporary state intervention in the form of so-called monitoring economy (Siegel) implies a complementary response of the public sector to the economic actions of the private sector taken through supporting the development of the propulsive sectors, technical progress incentives, infrastructure financing, fiscal benefits, subsidies, and so on. In this context, modern states pay special attention to the economic development of underdeveloped areas aimed at harmonizing global, structural, sectoral, regional, inter-regional, sub-regional and local development. To accelerate the development of underdeveloped regions in developed industrial countries numerous mechanisms are used: subsidies, grants, lower interest rates loans, fiscal incentives and benefits, industry-targeted sales of land and buildings in undeveloped areas at affordable prices, providing benefits to the industry in purchase of scarce raw materials, determining preferential tariffs for public service obligations of state-owned enterprises to invest in undeveloped areas, administrative ban on new investments in highly developed and urban overcrowded regions, providing government subsidies in various forms (premiums for the purchase of capital equipment, premiums for hiring new workers, co-financing research). The paper hereof analyses the experiences of European countries that can serve the creators of the economic policies of the neighboring developing countries in order to promote regional economic development and equality.
\end{abstract}

Keywords: Fiscal policy, sustainable development, subsidies, grants, fiscal benefits, fiscal incentives.

Address of the corresponding author:

Kristijan Ristić

䤵"kristijanristic.fpim@yahoo.com 


\section{INTRODUCTORY GOALS OF DEVELOPMENTS, FRAMEWORK \\ PREMISES - SUSTAINABLE GLOBAL}

The Triple Vision of Sustainable Development is documented in the Rio 2019 Summit document: Confirming the Sustainable Development Certificate, which will be achieved by fostering sustainable, inclusive and equitable economic growth, creating greater opportunities for all, reducing inequalities, increasing basic living standards by fostering equitable social development and inclusion, and fostering integrated and sustainable management of natural resources and ecosystems, which, inter alia, support economic, social and humane development, while facilitating the protection, regeneration, and resilience of ecosystems as new challenges arise.

The Millennium Sustainable Development Goals have added to the document "The future we want" also the global fight against extreme poverty as a prerequisite for sustainable development. The new global agenda has now included the world community, governments, businesses, scientists, leaders, NGOs and students in the historic decision-making process of a sustainable development strategy. This has helped world leaders to form, through the UN, a Network for Sustainable Development Solutions that includes health, education, agriculture, cities, the energy system, biodiversity protection and more. (Sachs, 2014)

The Sustainable Development Solution Network has proposed 10 Sustainable Development Goals, which shape the global management of a sustainable development economy. The first Sustainable Development Goal incorporates the eradication of extreme poverty, hunger, underdeveloped children, malnutrition and food provision insecurity, and providing the necessary support to disadvantaged countries. The second objective of sustainable development is to achieve economic development within the planetary boundaries, to secure sustainable production and consumption, to stabilize the global viewpoint, to ensure rational use of energy and to focus on growing food crops, building cities and environmental sustainability. The third objective of sustainable development implies the provision of effective education for all children and young people on their way towards a decent job, adequate qualifications and effective learning in line with technological changes. The fourth objective of sustainable development incorporates the achievement of gender equality and social inclusion, observing human rights and the principles of social mobility, eliminating excessive inequality of income and wealth. The fifth Sustainable Development Goal comprises human health and well-being, health care at all stages of life, primary health care services, the right to reproductive health, reducing child and maternal mortality, extending life expectancy, combating disease, healthy food, physical activity, and social aid. The sixth goal of sustainable development is to improve agricultural systems, increase rural productivity, rural infrastructure, and access to food production resources, ensure climate resilience, the sustainability of agriculture, sustainability in the food supply, protect water reserves, land, livestock, fisheries, and overall biodiversity. The seventh objective of sustainable development is to limit climate change, ensure sustainable energy, limit the emission of greenhouse gases and effects, move to the decarbonization of the energy system, including the availability of energy services to all. The ninth objective of sustainable development requires the empowerment of inclusive, productive and disputed cities based on inclusive, economically productive and environmentally sustainable elements of climate-resilient development and inequitable transformations in development. The ninth objective of sustainable development incorporates the provision of ecosystems and biodiversity services, good management of water and other natural resources, changes of marine and terrestrial ecosystems of local, regional and global importance in the direction of inclusive economic and human development. (Ristic \& Ristic, 2012)

Finally, the tenth objective of sustainable development implies the transformation of governance in the public sector, multinationals, local governments and "business pitches" to ensure transparency, accountability, participation and international rules in finance, corporate reporting trade, new technologies, intellectual property and elimination of corruption. (Doberman \& Nelson, 2013) 


\section{FINANCIAL INCENTIVES -} OVERVIEW AND EXPERIENCE OF EUROPE, CHALLENGES OF REGIONAL ADJUSTMENT

In the following pages, a historical overview of European experiences in the field of financial incentives will be presented. The recommendations impose a sufficient challenge on developing countries and on the road to adaptation on the accession path.

Subsidies: In Italy, subsidies are given for the production capacities in less developed regions for crafts and small industrial enterprises in up to $35-50 \%$ of total investments, for medium-sized enterprises $15-30 \%$ and for large enterprises 7 $12 \%$. For all businesses, this subsidy is increased by a fresh $10 \%$ for expenditures on machinery and equipment produced in the South and for the purchase of pollution prevention installations and equipment. In France, there are premiums for regional development of $12-15 \%$ of the invested funds, to offset costs of relocation of companies from the Paris region and up to $60 \%$ of costs, to offset costs of training experts, moving and housing workers, to assist local authorities when buying or preparing land up to $25 \%$ of the value of investments and for the purchase, construction and equipping of industrial buildings. In Germany, public financing is related to the formation or expansion of industrial enterprises in up to 10$25 \%$ of the value of an investment in new capacity and $15 \%$ of the expansion of existing capacity. In Denmark, subsidies are up to $25 \%$ of the value of investments. In Belgium, subsidies are granted in the case where investments are financed from own funds, in the amount of interest rate credit given in the case of credit financing. Interest bonuses or subsidies in equity may be replaced by "employment premiums" for a period of five years. Great Britain also provides subsidies for the acquisition of new investment equipment of up to $22 \%$ and premiums for any additional employment. In Ireland, subsidies go up to $40 \%$ of the value of investments in certain and up to $25 \%$ in other underdeveloped areas. For the modernization and reconstruction of existing capacities, subsidies amount up to $35 \%$ or up to $25 \%$, while for scientific and research work subsidies can go up to $50 \%$. In Luxembourg, subsidies are granted only if the project is financed by non-loan funds, up to a maximum of $15 \%$ of the investment value. In Sweden, the government stimulates employment in undeveloped areas through premiums, which are given to every individual who moves out of the so-called development center, and through traffic privileges. (Ristic \& Ristic, 2012)

When it comes to grants, there are grants in Italy in the amount of construction costs, grants of $10 \%$ for purchased equipment and appliances in developed areas, and 20\% for purchased equipment in underdeveloped areas. In Germany, the Fund for Regional Development Programs in Industry and Tourism grants an amount of $15 \%$ of investments, or up to $25 \%$ to reduce investment costs in border areas. In France, funding for the development of underdeveloped areas comes from the Territorial Development Fund, the Economic and Social Development Fund, and the local Regional Development Fund in the form of grants, subsidies and soft loans. In the United Kingdom, special grants are approved for the construction of special facilities to increase employment, grants for expenses related to the relocation of businesses and workers to undeveloped areas, and for the education of personnel and retraining of workers, construction grants, special purpose grants of up to $85 \%$ of the cleaning costs for neglected and polluted areas, special grants of up to $30 \%$ of infrastructure improvement costs and grants of up to $30 \%$ of wage costs in start-ups.

Interest bonuses are used in Belgium, Luxembourg, and Italy. In Belgium, companies investing in development zones receive bonuses on credits, loans, and liabilities. In Luxembourg, the bonus is granted on investment financing loans for industrial appliances, buildings, research, and human resources. In Italy, interest bonuses are provided to the industrial companies located in the south on the basis of investments in new capacities and modernization and reconstruction of existing installations in the amount of $30-50 \%$. In the Netherlands, the interest bonus is $3 \%$ over 15 years. In Germany, loans are given on more favorable terms of up to $50 \%$ of investment expenditures. (Ristic K. , 2017)

Fiscal benefits in Italy are approved for tax cuts on a portion of the profits reinvested in the South. The cuts are also applied to taxes on construction material, taxes on the purchase and transfer of 
land and buildings, electricity taxes and registration fees for new companies. In Belgium, there is an exemption from local labor and installed energy power tax, company registration, and real estate tax, as well as a reduction in the tax on reinvested profits. In France, there are cuts on land taxes and on reinvested profits and exemption from patent and inheritance taxes. In all EU Member States, there is rapid depreciation. In Italy, there is even double depreciation over three budget years, while in France there is an "exception" of depreciation up to $25 \%$ of construction costs. In the UK, initial write-offs are allowed up to $40 \%$ of the value of investments, while investments in the most underdeveloped regions enjoy the full benefit of accelerated writeoffs. The state grants special privileges in the form of free rent of factories or preferential lease of a newly built factory.

In Germany, grants and subsidies are allocated from public funds between $10 \%$ and $25 \%$ depending on the identified development segments. In Denmark, investment premiums are up to $25 \%$. In Germany, public aid is given in the form of loans to small and medium-sized enterprises, eligible loans to the manufacturing industry, investments in infrastructure and special benefits from social security funds. In the UK, local government funding is a source of public assistance to industry in underdeveloped regions, with the government prioritizing budgetary procurement from underdeveloped areas.

In addition to direct investment incentives, there are also state or local contributions to businesses in underdeveloped areas. In France, this share of the state is up to $35 \%$ of the company's capital. The government of Italy even founded a special body CASMEZ - Cassa del mezzogiorno (Eng. Fund for the South) (SIUSA, 2016), which participated in the capital of the company. In addition, Cassa del mezzogiorno (Felice \& Lepore, 2016) approved subsidies of up to $50 \%$ of the invested funds for the construction of industrial annexes, to those companies in the regions of the south for the construction of transport and port facilities, and land management, etc. In the UK, the state co-finances the cost of building new industrial facilities and the acquisition of new investment equipment. The share in the cost of construction, purchase, and renovation of industrial buildings is up to $20 \%$, and the share in the cost of facilities relocation is up to $80 \%$.

Tax incentives for equity investments are used in Argentina, Austria, Belgium, Denmark, Finland, France, Greece, the Netherlands, Indonesia, Italy, Japan, Canada, Ireland, Kenya, Luxembourg, Mexico, Germany, Portugal, Singapore, USA, Spain, Switzerland, Sweden, Finland, the United Kingdom, Guinea, Malaysia, Iran, the Philippines, Botswana, Bolivia. Profit tax incentives are used in Brazil, India, Chile, Greece, Honduras, Indonesia, Israel, Italy, China, Colombia, Morocco, Nigeria, Pakistan, Paraguay, Peru, Sri Lanka, Thailand, and Venezuela. Production tax incentives are used in Indonesia, China, Germany, Greece, Spain, Thailand, Uruguay, and the Philippines. Tax incentives on investment in labor are used in Mexico and Israel. Free trade zones are practiced in Brazil, the Philippines, Panama, China, South Africa and Paraguay. Consumption incentives are used in Belgium, Denmark, Finland, France, Greece, the Netherlands, Ireland, Italy, Canada, Spain, and Sweden. Other incentives (subsidized loans, subsidized land lease for industrial enterprises, provision of basic industrial infrastructure, preferential tariffs for utilities, preferential prices under contracts for deliveries to the state, state guarantees on loans to enterprises, technical assistance from state institutions for project development and supervision training, exemption from import duties on equipment, partial duty refund, preferential treatment of foreign joint venture partners, selective loans, beneficial cross-border lending, exemption from agricultural taxes in handicapped areas and exemptions from profit tax to the benefit of industrial and commercial enterprises in border areas) in Austria, Belgium, Brazil, Denmark, the Philippines, France, Finland, Greece, Ireland, Italy, Japan, Morocco, Peru, Spain, Sweden, Tanzania, Uruguay, Ecuador, Indonesia, Guatemala, Colombia, and Thailand.

The emphasis on stimulating additional investment in fixed assets, delivering goods and providing services required by the state and other fiscal and non-fiscal incentives in the policy of reducing regional disparities reflects a focus on supply rather than demand. However, what is the cost of an incentive for the national fiscal body and what are the alternative methods, which, in addition to the cost of incentive, reject the 
maximum benefits for the regional economy and national fiscal body by giving equivalent incentives are questions that leave no scientific answers? A standard analysis of price comparisons between the incentive given from fiscal and budgetary resources and the benefits of allocated incentives through production, employment, income, and taxes can demonstrate a rational incentive size in terms of the effectiveness of narrowing regional disparities and the efficiency of allocated resources. In this context, development policymakers should ensure that for each budget expenditure for a fiscal stimulus given, additional revenue for the national fiscal body should be made for income, personal income, consumption, revenue, and assets.

During the period 1980-2005, discussions were held in the EU on the reform of regional development policy and the Regional Development Fund, which was formed as an instrument that, through additional funding, reduces the disparities between the national economies of the Member States, prioritizing the development of the least-favored regions and coordination of national regional policies. The Fund's Regional Development Incentives policy was supported from four sources: (1) Beneficiary loans granted by the European Investment Banks, (2) aid from the Agrarian Fund, (3) additional funding from the Social Fund and (4) funds from the Regional Development Fund. In the period 1985-2008, a huge sum was raised through the Fund for the EU, to activate investments in which the Fund participated with $13-17 \%$. So far, there have been disputes over the functioning of the Fund over the question of who contributes and to what extent, and who benefits and in what amount, primarily because the Fund financed the budgets of countries allocated to regional development and that the fund's grants were a form of subsidy to the budgets of EU Member States. As a result, the Fund's reformulated strategy allocates funds into two categories: (1) funds allocated to the Member States within fiscal quotas and allocated according to the national regional development programs, and (2) funds used to finance joint projects. In this way, the Fund is not only an instrument of fundraising and allocation, but it also decides on the use of funds and coordinates national regional development policies with EU policy in order to arrive at a single, common regional development policy. (Ristic K. , 2017)

Fiscal incentives and benefits stimulate investment in research and the "production" of highly skilled personnel. Specific fiscal incentives stimulate rationalization and innovation. Imports of scientific research equipment are, as a rule, exempt from import duties (sales and customs taxes). Investments in human resources and the production of educational services, in essence, have the treatment of investments in "human capital" with a high yield rate for "investors" through increasing the newly created value and social productivity of labor. Realized results of scientific and research work in technical and technological progress repeatedly influence production. Therefore, science and education have lost their treatment of consumer goods and have acquired the status of indirectly manufacturing activities.

As activities of particular social interest and a leading activity within the entire sphere of social activities, educational and scientific needs are supported by fiscal resources. However, additional investment in science and education does not have fiscal treatment. Namely, investments in scientific and educational activities that are treated as material costs, covered by the reserve funds, are not fiscally treated. The same is the case with additional investments of the company with additional appropriations from income, earmarked investments, pooling of the funds, etc. Citizens' contribution to science and education is a deductible item in determining the fiscal burden of taxes on citizens' total income. Finally, the employment fund increases the mobility of highly skilled staff, with special staff gains attracting professional staff for underdeveloped areas.

\section{MACROECONOMIC POLICY OF THE EU AND SUSTAINABLE DEVELOPMENT: CRITICAL OBSERVATIONS, CHALLENGES OF THE REGIONAL ADAPTATION}

In this context, global hawks seek to establish comprehensive control over citizens, natural resources and capital in the form of democratic regulation of planetary flows and transnational affairs (interests). Such a global trend is 
accompanied by a dangerous gap between the forced "end of the nation-state" and the megalomaniac aspirations for the "proliferation of weak states" in the absence of effective global democratic institutions. Is it "globalization under a human disguise" and what remains of the "sustainable development" theory, which propagates an environmentally tolerable social, just and efficient economy? The globalist view of the world is linked to the privatization of stateowned (public) enterprises, an increase in the role of the private sector, a decrease in state interference in economic flows (deregulation), an increase in the freedom of flow of finances and foreign investment. Globalization is, therefore, a new starting point for the behavior of transnational corporations, changes in production and distribution technology, economies of scale, consumer behavior, liberalization of foreign trade and capital flows, widening the boundaries to locate businesses and ignoring the importance of a sustainable development economy. The pursuit of wealth leads to totalitarianism as wealth becomes new aggression. The point is that the economy must be spiritualized because the poor must be protected. The ethical issue is a more equal distribution of wealth, not just economic or social (though money has already become a religion). Globalism must not flourish by economic doctrines alone, as a "use of man" policy might take the stage. Then, indeed, Ethics and Nature would be replaced by Politics and Profit, which would push people into the bondage of a plastic thought, and not of sustainable development. In a financial vortex, global capitalism has introduced the anarchy of corporate dictatorships with the accelerated economic collapse of the entire world. The perverse connection between democracy and debt slavery is a direct consequence of the socalled "scum of the economy" (Napoleoni, 2008), which rules both life and death around the world. The Nobel-like raising a scientific attention that the economy should go in the direction of services and that ownership structure is a fundamental determinant of profitability has made it a bad practice for non-investment in a country to slip into crime, which is also a target function of the socalled corporate direct investment in the pills of structural adjustment, competitiveness, liberalization, privatization, and deregulation, as well as the destructive exploitation of cheap raw materials and unscrupulous increase in unemployment, pushing sustainable development on the path of global humanity. Europe wrongly strives to retain an advantage in the global economy by constantly reducing social security benefits and permanently increasing freedom for the owner of the capital. It is wrong to salvage financially devastated banks and companies by the means of the funds raised from the citizens' tax to the detriment of the science, education, health, and social protection, which are the epicenter point of sustainable development. (Marković, 2010)

Privatization, deregulation, liberalization, competition and innovation are all deregulators of institutional barriers to economic development and human well-being, with the development of the "tragedy of shared property" and "problematic state interventionism." State sovereignty is willingly surrendered to the global market, which improves efficiency and productivity, decreases prices and controls inflationary tendencies. Neoliberalism is suspicious of democracy and the law of the majority (which attacks the rights of individuals) and favors governance by the experts and the corporate elite (to isolate superfluous institutions such as the central bank). Neoliberal state, as a rule, favors the integrity of the financial system and the solvency of financial institutions. Neoliberalism lowers wages, increases worker exploitation increases job insecurity and eliminates protection at work. Social security has been minimized to the benefit of personal accountability and the strengthening of publicprivate partnerships. The state assumes a larger portion of the risk, while the private sector takes the larger portion of the profits. State coercion enhances the protection of corporate capital interests. Neoliberalism does not treat the nation with benevolence, and the liberal state, as a factor of competitiveness in the global market, mobilizes nationalism in promoting the business climate of the entrepreneurial spirit with emphasized individual freedoms and negation of sustainable development. (Stiglitz, 2015)

The collapse of the financial bubble, expressed through distorted asset prices, through the fleeing of the workforce, through the capital flight and through internal bankruptcies, has led to severe depression, which has crippled economic growth, lowered consumption and doubled unemployment. Economic ideas have, through 
international convergence, established a neoliberal program based on reducing the fiscal deficit, balancing the budget and controlling inflation, bypassing full employment and fair income distribution. Thus, the EU's neoliberal agenda became the cornerstone of macroeconomic policy, which relied on increasing autonomy, the cohesion of small and mediumsized enterprises, changing conditions for lending, lobbying, bribery, corruption, and election involvement. However, neo-liberalism could not function without the universal tendency to increase social inequality and growing marginalization without hiding the harsh reality of the rise of class power in the major financial centers of global capitalism, which is ravaging a sustainable development economy. In a wave of structural adjustment and neoliberal reforms, citizens are forced to live as market pendants. Stiglitz and Krugman, in favor of reforming global governance with better regular structures and tighter control over the financial system, have sharply pointed to the problem of income and asset inequality, which generate a structural crisis and degenerate structural reforms. Yet both global jobless and stagnant global economic recovery boils down to continued growth in debt-fuelled consumerism, as the US economy continues to rely on a huge amount of credit to maintain its wasteful functioning. So, what is "transitional" on the path to a perfect neoliberal world has already been recognized as the wrong utopian rhetoric of neoliberalism. The ideals of the neoliberal economy are already articulating a desire for alternative social relations. It does not subvert all human activities into the realm of markets but directs them towards sustainable development with sustainable finances and social inclusion. (Ristic K. , 2017)

\section{CONCLUSIONS}

The global economic crisis together with the implementation of the neoliberal project revealed the shift of the focus of the global economy from manufacturing to the finance sector as if economic activity no longer mattered. Thus, primitive private freedom has been formalized to gain profit from poverty in the form of a secretly designed private advantage such as competition, as a key impetus for development and a generator of monopoly. The presented analysis in the paper reinstates the state intervention in the form of European experience as a massive challenge for all countries in the accession process and with the aim of achieving regional economic equality. In this context, the final conclusion would be based on the statement that special financial and fiscal exemptions and incentives stimulate additional allocations for infrastructure needs. Economic transfers support investment in infrastructure. By issuing internal public debt and importing foreign accumulation by external borrowing creditworthy resources are recruited to finance regional cohesion and development, and finally, under eligible lending conditions, funds are reallocated into investment ventures in the area of infrastructure integrated regional sustainable development strategy. Based on the conclusions drawn, an additional one is that the local and executive levels ought to initiate sustainable regional development and cohesion.

\section{WORKS CITED}

Doberman, A., \& Nelson, R. (2013). Opportunities and Solutions for Sustainable Food Production. Background paper for High-Level Panel of Eminent Persons on the Post-2015 Development Agenda. New York: Sustainable Development Solutions Network. Retrieved from www.post2015hlp.org/wp-content/uploads/2013/05/Doberman-Nelson_Solutions-forSustainable-Food-Production.pdf

Felice, E., \& Lepore, A. (2016, 05 04). State intervention and economic growth in Southern Italy: the rise and fall of the 'Cassa per il Mezzogiorno' (1950-1986). Business History, 319-341. doi:10.1080/00076791.2016.1174214

Marković, D. (2010). Globalizacija i kriza globalne ekonomije. Beograd: Grafiprof .

Napoleoni, L. (2008). Rogue Economics - Capitalism New Reality. New York, USA: Seven storier Press.

Ristic, K. (2017). Tax policy in the function of innovations and entrepreneurship. FinConsult Tuzla, International science symposia. Fojnica: FinConsult. 
Ristic, Z., \& Ristic, K. (2012). Fiskalna ekonomija. Beograd: Etnostil.

Sachs, G. (2014). Doba održivog razvoja [The Age of Sustainable Development]. Belgrade: Centre for International Cooperation and Sustainable Development - CIRSD and Slulbeni glasnik.

SIUSA. (2016, 04 16). Cassa del mezzogiorno. CASMEZ. Retrieved from SIUSA: https://siusa.archivi.beniculturali.it/cgi-bin/pagina.pl?TipoPag=prodente\&Chiave=59569

Stiglitz, J. E. (2015). Velika podela [The Great Divide - Unequal Societies and What We Can Do About Them]. Novi Sad: Akademska knjiga.

Received for publication:

Revision received:

Accepted for publication:
24.11.2019

06.01 .2020

10.01.2020

\section{How to cite this article?}

Style - APA Sixth Edition:

Ristic, K., Pantovic, S., Gagovic, Z., \& Brckalo, M. (2020, January 15). Financial focusing on economic development sustainability. (Z. Cekerevac, Ed.) MEST Journal, 8(1), 93-100. doi:10.12709/mest.08.08.01.11

Style - Chicago Sixteenth Edition:

Ristic, Kristijan, Stanislav Pantovic, Zeljka Gagovic, and Marko Brckalo. 2020. "Financial focusing on economic development sustainability." Edited by Zoran Cekerevac. MEST Journal (MESTE) 8 (1): 93-100. doi:10.12709/mest.08.08.01.11.

Style - GOST Name Sort:

Ristic Kristijan [et al.] Financial focusing on economic development sustainability [Journal] // MEST Journal / ed. Cekerevac Zoran. - Belgrade - Toronto : MESTE, January 15, 2020. - 1 : Vol. 8. - pp. 93100.

Style - Harvard Anglia:

Ristic, K., Pantovic, S., Gagovic, Z. \& Brckalo, M., 2020. Financial focusing on economic development sustainability. MEST Journal, 15 January, 8(1), pp. 93-100.

Style - ISO 690 Numerical Reference:

Financial focusing on economic development sustainability. Ristic, Kristijan, et al. [ed.] Zoran Cekerevac. 1, Belgrade - Toronto : MESTE, January 15, 2020, MEST Journal, Vol. 8, pp. 93-100. 